\title{
Trends in minimal stream flows at eastern Slovakia
}

\author{
Martina Zelenakova ${ }^{\mathrm{a}}$, Pavol Purcz ${ }^{\mathrm{b}}$, Tatiana Solakova ${ }^{\mathrm{a}}$, Dorota Simonova ${ }^{\mathrm{c}}$, \\ Vlasta Ondrejka Harbulakova ${ }^{a}$ \\ ${ }^{a}$ Institute of Environmental Engineering, Technical University of Košice, Vysokoškolská 4, 04200 Košice, Slovakia \\ ${ }^{b}$ Institute of Construction Technology and Management, Technical University of Košice, Vysokoškolská 4, 04200 Košice, Slovakia \\ 'Slovak Hydrometeorological Institute, Ďumbierská 26, 04200 Košice, Slovakia
}

\begin{abstract}
The aim of this paper is to identify statistically significant trends in stream flow characteristics of low water content in the eastern Slovakia, which are used in the evaluation of hydrological drought. Methodology for evaluating hydrological drought is based on statistical analysis of observed minimal stream flows at river stations. This analysis was carried out for statistical data from 63 river stations lying in the eastern part of Slovakia, namely in Hornad, Poprad, Bodva, Bodrog river basins. The data were obtained from the Slovak Hydrometeorological Institute, Regional Centre Košice. Mann-Kendall statistical test identifies the frequency of minimal stream flow trends. Obtained results from the statistically significant trends in the stream flows are basement for the regionalization of the eastern Slovakia territory from the point of hydrological drought risk.
\end{abstract}

Keywords: hydrological drought; minimal stream flows; statistical tests; trend analysis.

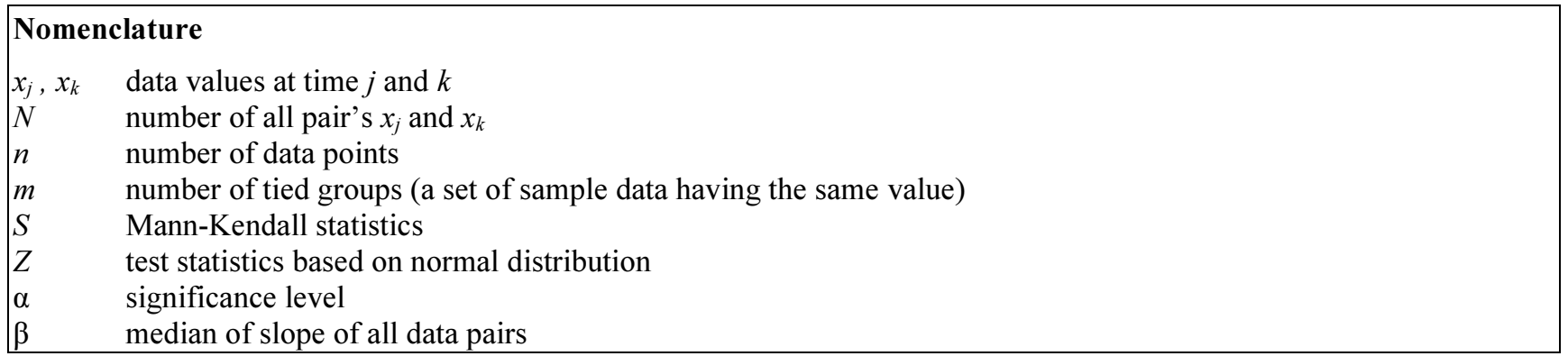

\section{Introduction}

Depending on where it shows a lack of water by the World Meteorological Organization - WMO (2004) classifies four basic types of drought, including: meteorological, hydrological, agricultural and socio-economic droughts [1]. The drought effects have been observed on all continents and over the past decade the frequency of drought increases.

Hydrological drought is a phenomenon which rise with existence of occurrence of no- precipitation period coupled with extreme temperatures. The genesis of hydrological extremes also affects the morphological conditions of origin, climatic factors, geological and hydrogeological conditions and anthropogenic activities [2], [3]. This type of drought is defined by long-term decrease in levels of surface water bodies (e.g. rivers, lakes, reservoirs and other) and drops in groundwater levels [4]. Low water content is proof of this type of drought [5]. On the mathematical-statistical evaluation of low water content are used to the flow and no-flow characteristics [6]. Low flow is defined as the smallest untouched average daily flow volume in time.

There is a distinction made between stream flow droughts and low flows (minimal flows). The main feature of a drought is said to be the deficit of water for some specific purpose. Low flows are normally experienced during a drought, but they feature only one element of the drought, i.e. the drought magnitude. Low flow studies are described as being analyses aimed at understanding the physical development of flows at a point along a river at a short-term (e.g. daily). Hydrological drought

Corresponding author: Martina Zelenakova. E-mail address: martina.zelenakova@tuke.sk

http://dx.doi.org/10.3846/enviro.2014.103

(C) 2014 The Authors. Published by VGTU Press. This is an open-access article distributed under the terms of the Creative Commons Attribution License, which permits unrestricted use, distribution, and reproduction in any medium, provided the original author and source are credited. 
analyses in terms of stream flow deficits are said to be studies over a season or longer time periods and in a regional context. A stream flow drought event definition quantitatively defines whether the flow can be regarded as being in a drought situation or not and gives the duration of a drought, whereas low flow indices characterize specific features of the low flow range [7].

During the past decades, many parametric and nonparametric techniques for the detection of long-term trends in time series were developed and applied [8]. A discussion on whether to choose a parametric or non-parametric test can be found in Hirsch et al. [9]. In the present study the widely used non-parametric tests was applied: the Mann-Kendall test, which is also recommended by the World Meteorological Organization (WMO) (1988) [10]. The non-parametric Mann-Kendall statistical test has been effectively and the most used to assess the significance of trend in hydrological time series [11-13].

The seasonality of hydrological characteristics is one of the key factors controlling the development and stability of natural ecosystems [14]. From a hydrological perspective, seasonality analysis is an appealing method for inferring flood generation mechanisms, which, in turn, supports other hydrological applications, such as hydrological regionalization [15].

The article presents a methodology for prediction of hydrological drought based on statistical testing of minimum monthly stream flows by non-parametric statistical test. The main objective is to identify low stream flow trends in selected 63 river stations in Eastern Slovakia in time interval 1975-2010. The Mann-Kendall non-parametric test has been used to detect trends in hydrological time series. Statistically significant trends have been determined from the trend lines and the prediction of hydrological drought risk in each month of hydrological year for the whole territory of Eastern Slovakia has been made.

\section{Materials and methods}

\subsection{Study area}

Study area, as was mentioned, is situated at eastern part of Slovakia (Fig. 1). In this territory 63 river stations are located. Evaluated stations are divided at stations affected by human activity and without human influence. The affected river stations are considered as a station where the hydrological regime altered the flow by interference of human activities (by water works, by excessive water abstraction, etc.).

\subsection{Data}

The first step in the evaluation was to obtain values of the minimal monthly flow for selected river stations. Hydrological data were provided by Slovak Hydrometeorological Institute Regional Centre Košice, at monthly intervals during years 1975-2010.

Basic datasets was created by chronologically ranking the values of low flows to the statistical files. One set of values is for one river station in mentioned 35-year period.

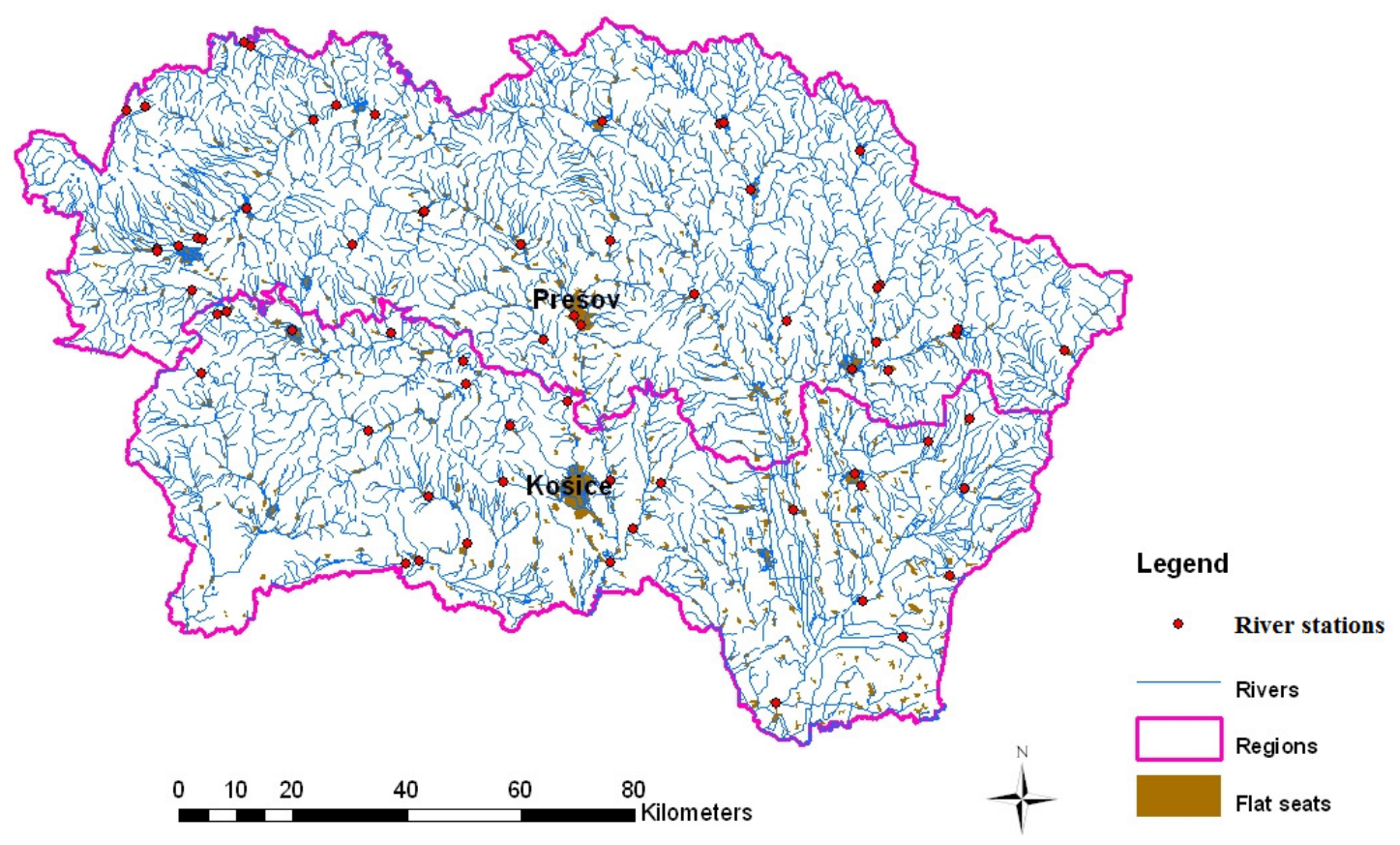

Fig. 1. A spatial distribution of river stations 


\subsection{Mann-Kendall test}

The Mann-Kendall test is a non-parametric statistical test. That means that we needn't make any assumptions about distribution of the random variable. A statistical hypothesis is an assumption about the distribution of a random variable generally. A statistical test of the hypothesis is a procedure which is used to find out whether we may "not reject" ("accept") the hypothesis, that is, act as though it is true, or whether we should "reject" it, that is, act as though it is false. This statistical test has a variety of applications for trend analysis [16].

Mann-Kendall test is following statistics based on standard normal distribution (Z), by using Eqn. (1).

$$
\begin{aligned}
& Z=\left\{\begin{array}{ccc}
S-1 / \sqrt{\operatorname{Var}(S)} & \text { if } & S>0 \\
0 & \text { if } & S=0 \\
S+1 / \sqrt{\operatorname{Var}(S)} & \text { if } & S<0
\end{array}\right. \\
& S=\sum_{k=1}^{n-1} \sum_{j=k+1}^{n} \operatorname{sgn}\left(x_{j}-x_{k}\right) \\
& \operatorname{sgn}\left(x_{j}-x_{k}\right)=\left\{\begin{array}{ccc}
+1 & \text { if } & \left(x_{j}-x_{k}\right)>0 \\
0 & \text { if } & \left(x_{j}-x_{k}\right)=0 \\
-1 & \text { if } & \left(x_{j}-x_{k}\right)<0
\end{array}\right. \\
& \operatorname{Var}(S)=\left[n(n-1)(2 n+5)-\sum_{i=1}^{m} t(t-1)(2 t+5)\right] / 18
\end{aligned}
$$

According to this test, the null hypothesis H0 states that the depersonalized data $\left(x_{1}, \ldots, x_{\mathrm{n}}\right)$ is a sample of $\mathrm{n}$ independent and identically distributed random variables. The alternative hypothesis H1 of a two-sided test is that the distributions of $x_{k}$ and $x_{j}$ are not identical for all $k, j \leq \mathrm{n}$ with $k \neq j$.

The value $\alpha$ is called the significance level; we choose $\alpha=0.05$ and $Z_{\alpha / 2}$ is a table value for normal distribution, in this case $Z_{\alpha / 2}=1.95996$. Hypothesis $\mathrm{H} 0$ - no trend is if $\left(Z<Z_{\alpha / 2}\right)$ and $\mathrm{H} 1$ - there is a trend if $Z>Z_{\alpha / 2}$. Moreover, the value of $Z$ gives further information about any increasing or decreasing of the trend, but not its magnitude exactly [15-17].

The magnitude of the trend was determined using Sen's estimator. Sen's method assumes a linear trend in the time series and has been widely used for determining the magnitude of trend in hydro-meteorological time series [18-21]. In this method, the slopes $(\beta)$ of all data pairs are first calculated by

$$
\beta=\operatorname{Median}\left(\left(x_{j}-x_{k}\right) /(j-k)\right)
$$

for $i=1,2, \ldots, N$, where $x_{j}$ and $x_{k}$ are data values at time $j$ and $k(j>k)$, respectively and $N$ is a number of all pairs $x_{j}$ and $x_{k}$.

A positive value of $\beta$ indicates an upward (increasing) trend and a negative value indicates a downward (decreasing) trend in the time series. The process of statistical analysis was performed according to the scheme in Fig. 2.

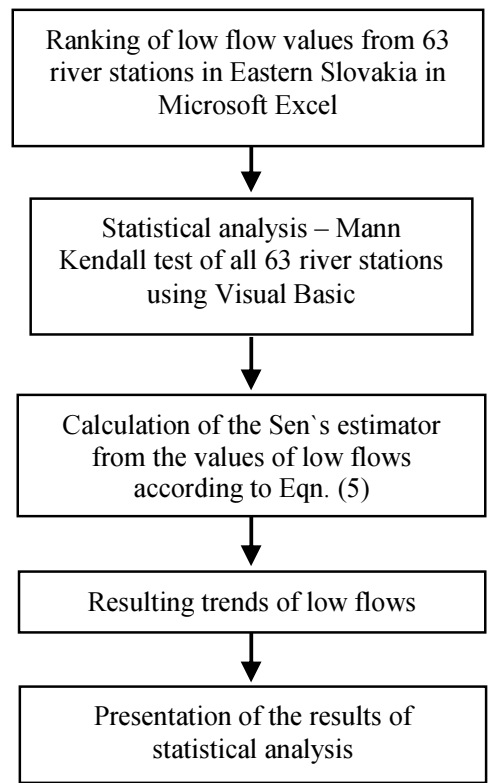

Fig. 1. Process of the statistical analysis 
All mathematical Equations from (1) to (5) were programmed in Visual Basic in Microsoft Excel 2003 and sizes of significant trends in individual river stations were calculated in each month.

\section{Results}

\subsection{Equations and formulae}

After the statistical analysis each river station is assigned trends of low flow in each month. Tables 1 to 4 present statistically significant trends in the months with the favourable development water levels shown in double plus sign, if prevailing water levels drop are shown in double minus sign. Stations affected by human activity are highlighted in dark colour.

Table 1. Statistically significant trends in river stations in river basin Hornád

\begin{tabular}{|c|c|c|c|c|c|c|c|c|c|c|c|c|c|}
\hline \multirow[b]{2}{*}{ No } & \multirow[b]{2}{*}{ Station } & \multicolumn{12}{|c|}{ Hydrological year } \\
\hline & & $\begin{array}{l}\bar{\Xi} \\
\text { है } \\
\text { ¿े } \\
\text { Z }\end{array}$ & 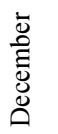 & $\underset{\Xi}{\stackrel{\Xi}{\Xi}}$ & 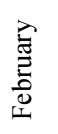 & 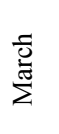 & 宓 & $\sum^{\grave{E}}$ & $\stackrel{\Xi}{\Xi}$ & $\stackrel{\lambda}{\Xi}$ & $\begin{array}{l}\overrightarrow{\mathscr{n}} \\
\stackrel{00}{\Xi} \\
\stackrel{2}{Z}\end{array}$ & $\begin{array}{l}\bar{\Xi} \\
\bar{\Xi} \\
\overline{0} \\
\stackrel{0}{0} \\
\tilde{n}\end{array}$ & $\begin{array}{l}\overline{0} \\
0 \\
0 \\
0 \\
0\end{array}$ \\
\hline 1 & Hranovnica & ++ & ++ & + & + & + & + & + & + & + & ++ & ++ & ++ \\
\hline 2 & Hrabušice-Hornád & + & + & + & + & - & - & -- & - & + & + & ++ & + \\
\hline 3 & $\begin{array}{l}\text { Hrabušice-Podlesok- } \\
\text { Biela Voda }\end{array}$ & ++ & + & + & + & + & + & - & - & + & ++ & ++ & ++ \\
\hline 4 & Spišská Nová Ves & + & + & + & + & + & - & - & -- & - & + & + & + \\
\hline 5 & Spišské Vlachy & ++ & ++ & ++ & ++ & + & + & + & ++ & ++ & ++ & ++ & ++ \\
\hline 6 & Margecany & + & - & - & - & - & - & -- & - & - & + & + & + \\
\hline 7 & Stratená & + & + & + & ++ & + & - & - & -- & + & + & + & + \\
\hline 8 & Švedlár na Hrabliach & + & + & + & + & + & + & - & - & - & + & + & ++ \\
\hline 9 & Jaklovce & - & - & - & - & - & -- & -- & -- & -- & - & - & - \\
\hline 10 & Košická Belá & ++ & + & + & + & + & + & + & + & + & + & + & ++ \\
\hline 11 & Kysak & - & - & - & - & - & - & - & - & - & + & - & - \\
\hline 12 & Nižné Repaše & ++ & ++ & ++ & ++ & + & + & + & ++ & ++ & ++ & + & ++ \\
\hline 13 & Brezovica & + & + & -- & - & + & + & - & - & - & + & + & + \\
\hline 14 & Sabinov & + & + & + & + & + & + & - & - & + & + & + & + \\
\hline 15 & Prešov-Torysa & - & - & - & - & - & - & -- & -- & -- & - & - & - \\
\hline 16 & Demjata-Sekčov & ++ & + & + & - & - & - & - & -- & - & + & - & + \\
\hline 17 & Prešov-Sekčov & + & + & - & - & - & - & - & - & - & + & + & + \\
\hline 18 & Košické Olšany & - & - & - & - & -- & - & -- & -- & -- & - & - & - \\
\hline 19 & Svinica-Svinický potok & + & + & + & + & + & + & - & - & - & -- & - & + \\
\hline 21 & Ždaňa & - & - & - & - & - & - & - & -- & - & - & - & - \\
\hline \multicolumn{2}{|c|}{$\begin{array}{l}\text { Number of decreasing trends of } \\
\text { low flows }\end{array}$} & 5 & 6 & 8 & 9 & 10 & 12 & 17 & 17 & 13 & 6 & 8 & 5 \\
\hline \multicolumn{2}{|c|}{ Decreasing trends in \% } & 24 & 29 & 38 & 43 & 48 & 57 & 81 & 81 & 62 & 29 & 38 & 24 \\
\hline
\end{tabular}

Table 2. Statistically significant trends in river stations in river basin Bodva

\begin{tabular}{|c|c|c|c|c|c|c|c|c|c|c|c|c|c|}
\hline \multirow[b]{2}{*}{ No } & \multirow[b]{2}{*}{ Station } & \multicolumn{12}{|c|}{ Hydrological year } \\
\hline & & $\begin{array}{l}\bar{\Xi} \\
\bar{E} \\
\bar{D} \\
0 \\
z\end{array}$ & 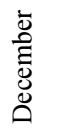 & $\underset{\Xi}{\stackrel{\Xi}{\Xi}}$ & 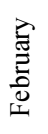 & 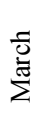 & 竞 & $\stackrel{\vec{E}}{\Sigma}$ & $\stackrel{\Xi}{\Xi}$ & $\stackrel{\gtrsim}{\Xi}$ & 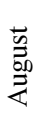 & 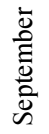 & $\begin{array}{l}\overline{0} \\
\frac{1}{0} \\
0 \\
0\end{array}$ \\
\hline 1 & Nižný Medzev & - & + & + & - & - & - & - & - & -- & - & - & - \\
\hline 2 & Moldava nad Bodvou & - & + & + & - & - & - & -- & -- & - & - & - & - \\
\hline 3 & Hýl’ov-Ida & + & ++ & + & + & + & - & - & - & - & - & + & ++ \\
\hline 4 & Turňa nad Bodvou & - & - & - & - & - & - & -- & -- & - & - & - & - \\
\hline
\end{tabular}


M. Zelenakova et al. / The $9^{\text {th }}$ Conference Environmental Engineering. Selected Papers, Article number: enviro.2014.103

\begin{tabular}{|c|c|c|c|c|c|c|c|c|c|c|c|c|}
\hline Host'ovce-Turňa & - & - & - & - & - & -- & -- & -- & -- & - & - & -- \\
\hline $\begin{array}{l}\text { Number of decreasing trends of } \\
\text { low flows }\end{array}$ & 4 & 2 & 2 & 4 & 4 & 5 & 5 & 5 & 5 & 5 & 4 & 4 \\
\hline Decreasing trends in \% & 80 & 40 & 40 & 80 & 80 & 100 & 100 & 100 & 100 & 100 & 80 & 80 \\
\hline
\end{tabular}

Table 4. Statistically significant trends in river stations in river basin Bodrog

Hydrological year

\begin{tabular}{|c|c|c|c|c|c|c|c|c|c|c|c|c|}
\hline No & Station & $\begin{array}{l}\bar{D} \\
\text { है } \\
\text { ठ } \\
z\end{array}$ & 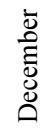 & 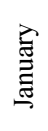 & 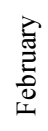 & $\begin{array}{l}\frac{\sigma}{d} \\
\text { J }\end{array}$ & $\overline{\bar{z}}$ & $\stackrel{\vec{J}}{\Sigma}$ & 导 & 文 & 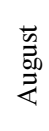 & $\begin{array}{l}\bar{\Delta} \\
\bar{\Xi} \\
\overline{0} \\
\overline{0}\end{array}$ \\
\hline
\end{tabular}

\begin{tabular}{|c|c|c|c|c|c|c|c|c|c|c|c|c|c|}
\hline 1 & Medzilaborce & + & - & + & + & + & - & - & - & -- & - & - & + \\
\hline 2 & Jabloň & + & + & + & ++ & + & + & + & + & + & - & - & + \\
\hline 3 & Kokošovce & - & - & - & - & - & - & - & -- & -- & -- & - & - \\
\hline 4 & Udavské & + & - & + & + & + & + & - & - & - & - & - & + \\
\hline 5 & Snina-Cirocha & + & + & + & - & - & + & - & + & - & ++ & + & + \\
\hline 6 & Snina-Pčolinka & + & + & + & - & + & + & + & + & - & - & - & - \\
\hline 7 & Kamenica nad Cirochou & ++ & ++ & ++ & ++ & ++ & + & ++ & ++ & ++ & ++ & ++ & ++ \\
\hline 8 & Humenné & + & + & + & - & - & + & - & + & - & - & + & + \\
\hline 9 & Michalovce-Stráňany & - & - & - & - & + & -- & -- & -- & -- & -- & - & -- \\
\hline 10 & Jovsa & + & + & ++ & + & + & + & + & - & + & + & + & ++ \\
\hline 11 & Michalovce-Med'ov & - & - & - & + & + & - & - & - & - & + & -- & -- \\
\hline 12 & Ulič & + & + & + & ++ & + & ++ & + & - & - & - & - & + \\
\hline 13 & Lekárovce & - & - & - & - & - & - & - & - & -- & -- & -- & - \\
\hline 14 & Remetské Hámre & + & - & + & + & + & - & - & - & - & - & - & - \\
\hline 15 & Sobrance & + & + & + & + & + & + & + & + & + & + & + & + \\
\hline 16 & Ižkovce & - & + & - & + & + & + & - & -- & -- & - & -- & -- \\
\hline 17 & Vel'ké Kapušany & - & - & - & - & - & - & -- & -- & -- & -- & -- & - \\
\hline 18 & Bardejov & + & + & ++ & ++ & + & + & - & - & + & + & + & + \\
\hline 19 & Hanušovce nad Topl'ou & - & - & - & - & - & -- & -- & -- & -- & -- & -- & -- \\
\hline 20 & Svidník-Ondava & + & - & + & + & + & ++ & + & + & - & + & + & + \\
\hline 21 & Svidník-Ladomírka & + & - & + & + & + & + & + & - & - & - & - & - \\
\hline 22 & Stropkov & - & - & - & - & - & - & -- & -- & -- & - & -- & -- \\
\hline 23 & Jasenovce & + & + & + & ++ & + & + & + & - & - & + & + & + \\
\hline 24 & Horovce & + & + & + & + & + & + & - & + & + & + & + & + \\
\hline 25 & Streda nad Bodrogom & - & - & - & - & - & - & - & -- & -- & - & - & - \\
\hline \multirow{2}{*}{\multicolumn{2}{|c|}{$\begin{array}{c}\text { Number of decreasing trends of } \\
\text { low flows } \\
\text { Decreasing trends in \% }\end{array}$}} & 9 & 13 & 9 & 10 & 8 & 10 & 16 & 17 & 19 & 16 & 16 & 12 \\
\hline & & 36 & 52 & 36 & 40 & 32 & 40 & 64 & 68 & 76 & 64 & 64 & 48 \\
\hline
\end{tabular}

Table 4. Statistically significant trends in river stations in river basin Poprad

\begin{tabular}{|c|c|c|c|c|c|c|c|c|c|c|c|c|c|}
\hline \multirow[b]{2}{*}{ No } & \multirow[b]{2}{*}{ Station } & \multicolumn{12}{|c|}{ Hydrological year } \\
\hline & & $\begin{array}{l}\bar{\Xi} \\
\text { है } \\
\text { Dे } \\
\text { Z }\end{array}$ & 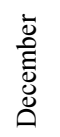 & 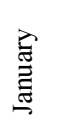 & $\begin{array}{l}\vec{E} \\
\stackrel{0}{0} \\
0 \\
01\end{array}$ & 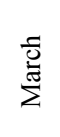 & $\overline{\bar{z}}$ & $\sum^{\mathrm{J}}$ & $\stackrel{\Xi}{\Xi}$ & \} $&{\text { 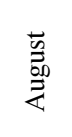 }} &{\text { 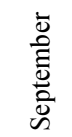 }} &{\text { 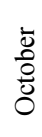 }} \\
{\hline 1} &{\text { Ždiar-Lysá Pol’ana }} &{+} &{-} &{+} &{+} &{++} &{+} &{+} &{--} &{-} &{--} &{--} &{-} \\
{\hline 2} &{\text { Ždiar-Podspády }} &{-} &{\text { - }} &{-} &{-} &{+} &{+} &{+} &{-} &{-} &{--} &{--} &{-} \\
{\hline 3} &{\text { Červený Kláštor Kúpele }} &{++} &{+} &{+} &{+} &{+} &{+} &{+} &{++} &{++} &{+} &{+} &{+} \\
{\hline 4} &{\text { Červený Kláštor-Dunajec }} &{+} &{+} &{+} &{++} &{+} &{-} &{-} &{-} &{-} &{-} &{-} &{+} \\
{\hline 5} &{\text { Svit-Poprad }} &{-} &{-} &{-} &{+} &{+} &{+} &{+} &{-} &{-} &{--} &{-} &{-} \\
{\hline 6} &{\text { Svit-Mlynica }} &{+} &{+} &{+} &{++} &{+} &{-} &{\text { - }} &{--} &{--} &{-} &{-} &{\text { - }} \\
{\hline 7} &{\text { Poprad-Vel'ká }} &{++} &{+} &{+} &{+} &{+} &{+} &{+} &{+} &{+} &{+} &{+} &{+} \\
$\hline
\end{tabular}


M. Zelenakova et al. / The $9^{\text {th }}$ Conference Environmental Engineering. Selected Papers, Article number: enviro.2014.103

\begin{tabular}{|c|c|c|c|c|c|c|c|c|c|c|c|c|c|}
\hline 8 & Poprad-Matejovce & + & + & + & + & + & ++ & + & + & + & + & + & + \\
\hline 9 & Kežmarok-L’ubica & ++ & ++ & ++ & ++ & + & + & ++ & + & + & ++ & + & ++ \\
\hline 10 & Nižné Ružbachy & + & - & - & - & - & - & + & - & - & - & - & - \\
\hline 11 & Hniezdne-Kamienka & ++ & + & ++ & ++ & ++ & + & + & ++ & ++ & + & + & + \\
\hline 12 & Chmel'nica & + & - & - & + & - & - & - & - & - & - & - & - \\
\hline \multicolumn{2}{|c|}{$\begin{array}{l}\text { Number of decreasing trends of } \\
\text { low flows }\end{array}$} & 1 & 4 & 2 & 2 & 1 & 2 & 3 & 7 & 7 & 7 & 7 & 6 \\
\hline \multicolumn{2}{|c|}{ Decreasing trends in \% } & 8 & 33 & 17 & 17 & 8 & 17 & 25 & 58 & 58 & 58 & 58 & 50 \\
\hline
\end{tabular}

\subsection{Construction of references}

Evaluation of the trend analysis (Tables 1-4) of the monthly stream flow series at 63 river stations in river basins Hornád, Poprad, Bodva and Bodrog in the eastern Slovakia in 35 years' time period has been performed by the Mann-Kendall test and was found that the river basins: Hornád and Bodva are most vulnerable to drought. The optimal regime of low flows is in those river basins: Poprad and Bodrog. Fields marked with dark colour (in Tables 1-4) presents the months in which the majority of stations have a significant trends of low flows. Most of the decreasing trends of low flows in the streams in Eastern Slovakia in river catchments Poprad, Hornád, Bodva a Bodrog can be expected during summer months - May, June, July, and August as was proved by Mann Kendall test. In river stations affected by human activity are negative trends in water levels especially in Kysak, Brezovica, Ždaňa, Host'ovce and in Michalovce - Stráňany.

\section{Conclusion}

The article presents a methodology for prediction of hydrological drought risk based on statistical testing of flow characteristics of low water content (minimum monthly stream flow) with non-parametric statistical test. The main objective was to identify low flow trends in the selected 63 river stations in Eastern Slovakia in time period 1975-2010. The MannKendall non-parametric test was used to detect trends in hydrological time series. Statistically significant trends have been determined from the trend lines and the prediction of hydrological drought risk regionalization in each month of hydrological year for the whole territory of Eastern Slovakia was made. Some of stream flow records in rivers in Eastern Slovakia are affected by human activities and another are without its influence.

Statistical tests can detect the existence of trends in hydrological time series. The purpose of the tests is to detect a statistically significant trend of decrease or increase of low flow values. Non-parametric Mann-Kendall test doesn't make assumption on the probability distribution of random variable. It has wide application in testing of hydro-meteorological characteristics.

The results confirmed the rising incidence trends of decreasing of low flows in the streams in Eastern Slovakia in river catchments Poprad, Hornad, Bodva a Bodrog. Hydrological drought can be expected in almost summer months during the year - May, June, July, and August. This methodology was used in the risk analysis of hydrological drought in individual regions. In the complex vulnerability assessment of territory owing to drought is essential to take into account also the parameters as temperature, precipitation and groundwater levels.

\section{Acknowledgements}

This work has been supported by the Slovak Research and Development Agency SK-PT-0001-12.

\section{References}

[1] Mishra, K.; Singh, P. 2010. A review of drought concepts, J. Hydrol 263: 203-212.

[2] Korytarova, J.; Slezingr, M.; Uhmannova, H. 2007. Determination of Potential Damage to Representatives of Real Estate Property in Areas Afflicted by Flooding, J.Hydrol.Hydromech 55: 282-285.

[3] Pelikan, P.; Slezingr, M. 2011. Methodology for the establishment of physical and geometric properties of a drainage basin, Acta univ. agric. et silvic. Mendel. Brunen 5: 265-270.

[4] Demeterova, B.; Skoda, P. 2008. Low flow in selected streams of Slovakia, J.Hydrol.Hydromech 57: 55-59. (in Slovak)

[5] Szolgay, J.; Dzubak, M.; Hlavcova, K. 1994. Hydrology, Runoff process and hydrology of surface water Slovak Technical University, Bratislava. (in Slovak).

[6] Demeterova, B.; Skoda, P.; Magulova, R.; Gapelova, V.; Sičova, B.; Liova, S., 2006. Hydrological limits. Low water content. Analysis of water balance in drought year with a new flow limits, Task of SHMI 6321-00, Final report-part 2, Slovak Hydrometeorological Institute, Bratislava. (in Slovak).

[7] Hisdal, H.; Tallaksen L.M., 2000. Impact of Droughts in Europe. Drought Event Definition, Technical Report No. 6.

[8] Hirsch, R. M.; Alexander, R. B.; Smith, R. A. 1991. Selection of methods for the detection and estimation of trends in water quality, Water Resource Research 27: 803-813. http://dx.doi.org/10.1029/91WR00259

[9] Hirsch, R. M.; Slack, J. R.; Smith, R. A. 1982. Techniques of trends analysis for monthly water quality data, Water Resource Research 18: 107-121. http://dx.doi.org/10.1029/WR018i001p00107 
[10] World Meteorological Organization (WMO), 2008. Guide to Hydrological Practices No 1211/168 on hydrology - from measurement to hydrological information, Volume I. World Meteorological Organization, Switzerland.

[11] Kendall, M. G. 1975. Rank Correlation Measures, London: Charles Griffin.

[12] Mann, H. B. 1945. Non-parametric tests against trend, Econometrica 13: 245-259. http://dx.doi.org/10.2307/1907187

[13] Burn, D. H.; Elnur, M. A. H., 2002. Detection of hydrologic trends and variability, J. Hydrol 25: 107-122. http://dx.doi.org/10.1016/S00221694(01)00514-5

[14] Parajka, J.; Kohnova, S.; Merz, R.; Szolgay, J.; Hlavcova, K.; Blöschl, G., 2009. Comparative analysis of the seasonality of hydrological characteristic in Slovakia and Austria, Hydrological Sciences Journal 54(3): 456-473. http://dx.doi.org/10.1623/hysj.54.3.456

[15] Gaal, L.; Szolgay, J.; Kohnova, S.; Parajka, J.; Merz, R; Viglione, A.; Blöschl, G., 2012. Flood timescales: Understanding the interplay of climate and catchment processes through comparative hydrology, Water Resources Research 48, W04511. http://dx.doi.org/10.1029/2011WR011509

[16] Santos, J. F.; Pulido-Calvo, I.; Portela, M. M., 2010. Spatial and temporal variability of droughts in Portugal, Water Resour. Res 46. W03503. http://dx.doi.org/10.1029/2009WR008071

[17] Önöz, B.; Bayazit, M., 2003. The Power of Statistical Tests for Trend Detection, Turkish J. Eng. Env. Sci 27: $247-251$.

[18] Sen, P. K. 1968. Estimates of the regression coefficient based on Kendall's tau, Journal of the American Statistical Association 63: 1379-1389. http://dx.doi.org/10.1080/01621459.1968.10480934

[19] Lettenmaier, D. P.; Wood, E. F.; Wallis, J. R. 1994. Hydro-climato-logical trends in the continental United States, 1948-1988, J. of Climate 7: 586607. http://dx.doi.org/10.1175/1520-0442(1994)007<0586:HCTITC $>2.0$.CO;2

[20] Yue, S.; Hashino, M. 2003. Temperature trends in Japan: 1900-1990, Theoretical and Applied Climatology 75: 15-27.

[21] Partal, T.; Kahya, E. 2006. Trend analysis in Turkish precipitation data, Hydrological Processes 20: 2011-2026. http://dx.doi.org/10.1002/hyp.5993 